\title{
Effect of Body Mass Index on the Prognosis in Lipophilic Drug Intoxication
}

\author{
Lipofilik Illaç Zehirlenmesinde Vücut Kitle İndeksinin Prognoza Etkisi \\ @ilker Kaçer', @Ramazan Köylü', @Nazire Belgin Akıllı' \\ 'Health Sciences University Konya Training And Research Hospital, Department of Emergency Medicine, Konya, Turkey
}

\begin{abstract}
Introduction: The aim of this study was to investigate the effects of body mass index (BMI)c on the prognosis of lipophilic drug intoxication in patients who are admitted to the emergency units.

Material and Method: The files of the patients who presented to the emergency department with lipophilic drug poisoning between January 2014 and August 2016 were reviewed. Demographic characteristics, medications taken, complaints at the time of admission, and physical examination findings were recorded. BMIs of the patients were calculated. The group was created according to their BMI. These groups were compared.
\end{abstract}

Results: 202 patients were included in the study. Among the participants, $75(37,1 \%)$ were in the 18-24,9 BMl interval, and $127(62,9 \%)$ were $\geq 25$. A statistically significant difference was observed between BMI groups regarding age, active complaint, hypertension, coronary artery disease, psychiatric disease, atrial fibrillation, need for atropine, need for pralidoxime (PAM), duration of mechanical ventilation and duration of intensive care unit stay $(p<0,05)$.

Conclusions: The need for atropine and PAM, duration of mechanical ventilation and intensive care unit stay were observed to be higher in patients with high BMI. BMI maybe used as a prognostic factor for the prognosis of patients with lipophilic drug intoxication; however, more comprehensive studies are needed to support the finding.

Keywords: Lipophilic drug, body mass index, poisoning, emergency medicine
Öz

Giriş: Bu çalışmanın amacı, acil servislere başvuran hastalarda vücut kitle indeksinin (VKI) lipofilik ilaç zehirlenmesinin prognozuna etkisini araştırmaktır.

Gereç ve Yöntem: Ocak 2014 - Ağustos 2016 tarihleri arasında lipofilik ilaç zehirlenmesi nedeniyle acil servise başvuran hastaların dosyaları incelendi. Demografik özellikler, alınan ilaçlar, başvuru anında şikayetler ve fizik muayene bulguları kaydedildi. Hastaların vücut kitle indeksleri hesaplandı. BMI'lerine göre grup oluşturuldu ve karşılaştıııldı.

Bulgular: Çalışmaya 202 hasta dahil edildi. Katılımcıların 75'i (\%37,1) 18-24,9 VKI aralığında, 127'si (\%62,9) $\geq 25$ idi. VKI grupları arasında yaş, aktif yakınma, hipertansiyon, koroner arter hastalığı, psikiyatrik hastalık, atriyal fibrilasyon, atropin ihtiyacı, pralidoksim ihtiyacı (PAM), mekanik ventilasyon süresi ve yoğun bakımda kalış süresi açısından istatistiksel olarak anlamlı farklılık gözlendi ( $p<0,05)$.

Sonuç: VKI'si yüksek hastalarda atropin ve PAM intiyacI, mekanik ventilasyon süresi ve yoğun bakımda kalış süresinin daha yüksek olduğu görüldü. BMI, lipofilik ilaç intoksikasyonu olan hastaların prognozu için prognostik bir faktör olarak kullanılabilir; ancak bulguyu desteklemek için daha kapsamlı çalışmalara intiyaç vardır.

Anahtar Kelimeler: Lipofilik ilaç, vücut kitle indeksi, zehirlenme, acil tıp

Corresponding (Illetişim): Ilker Kaçer, Aksaray University Aksaray Education and Research Hospital, Department of Emergency Medicine, Aksaray, Turkey

E-mail (E-posta): ik0626@hotmail.com

Received (Geliş Tarihi): 06.04.2021 Accepted (Kabul Tarihi): 06.05.2021 


\section{INTRODUCTION}

Intoxication is the functional impairment of an organism that meets a specific agent. ${ }^{[1,2]}$ Drug intoxications are emergencies that are frequently observed in emergency units and accompanied by high mortality and morbidity rates. One of the most important factors that define the prognosis is the time between drug intake and treatment; the treatment should be begun as soon as possible. Toxic agent elimination methods that are performed at the correct timing are life-saving. ${ }^{[3,4]}$ Factors that affect the absorption in drug intoxication are: the route of agent administration or exposure, chemical and physical characteristics of the agent (molecular size, lipid solubility (lipophility), and the degree of ionization). ${ }^{[4]}$

Direct measurements of one's body composition include underwater weighing, skin folding measurement, bioelectric impedance analysis, and double energy X-ray absorptiometry. These direct methods are practical; however, they are not applicable for most health workers. Therefore, indirect methods have been developed, which include measurements of height and weight of the patients according to gender. BMI, body surface area, ideal body mass, non-fat body mass, and recently defined normal mass are frequently used weight and height definers in clinical practice and pharmacokinetic studies. BMI is a value that is obtained by division of the patient's body weight $(\mathrm{kg})$ to the square of the height of the patient $(\mathrm{m})\left(\mathrm{BMl}=\mathrm{kg} / \mathrm{m}^{2}\right){ }^{[5]}$

Since lipophilic drugs accumulate in adipose tissue, the duration of their stay in the body increases, and then they may undergo redistribution. Accordingly, intoxication status may take longer and more severe in lipophilic drug intoxication.6 Since lipophilic agents such as verapamil, organophosphate compounds, clomipramine, propranolol, bupropion, lamotrigine, sertraline, quetiapine, haloperidol and, local anesthetics are highly soluble in fat tissue, BMI would have an important prognostic role in intoxications ${ }^{[6-8]}$ However, the prognostic significance of BMI in lipophilic drug intoxication is not known. In our study, we aimed to determine the prognostic significance of BMI in lipophilic drug intoxication.

\section{MATERIAL AND METHOD}

The study was conducted in compliance with the 1975 Declaration of Helsinki and approved by Necmettin Erbakan University School of Medicine, Scientific Research Evaluation Committee with a decision no: $2016 / 16-96$. Written or verbal informed consent was obtained from each patient included in the study.

Patients who had been hospitalized in the toxicology intensive care unit of Konya Research and Training Hospital due to lipophilic drug intoxication between January 2014 and August 2016, were retrospectively investigated. The inclusion criteria were: 18 years of age and older, admission to the emergency unit due to lipophilic drug intoxication, hospitalization in the toxicology intensive care unit of emergency medicine clinics. The exclusion criteria were: age younger than 18 years, pregnancy, non-lipophilic drug intoxications, and discharge before 48 hours due to completed therapy or patient's desire.

The BMIs of the patients included in the study were calculated and the effects on the prognosis were investigated. The demographic characteristics, age, gender, weight, height, type of the drug exposed, clinical symptoms and findings, vital signs on admission, time from drug intake to admission to the emergency unit, complete blood count results, biochemical indicators, $\mathrm{pH}, \mathrm{HCO}_{3}$, lactate and $\mathrm{pCO}_{2}$ levels in the venous blood of the patients who had been admitted to the emergency unit with lipophilic drug intoxication and for whom a judicial patient file was formed, were evaluated. GCSs were calculated from medical records The Fakir Hercules weighing machine was used in the intensive care units. The weight and height information were used to calculate the BMIs of the patients. The duration of hospital stay and status of discharge or exitus were checked from the records. Two groups were created and compared according to BMI.

The data were analyzed using the SPSS 15.0 program package. Compliance with the normal distribution was investigated using visual and analytic methods. The numerical data obtained from descriptive analysis were expressed as mean \pm standard deviation if normally distributed, and as interquartile range (IQR) if non-normally distributed. The nominal data were expressed as percentages. Differences between the groups were compared using chi-square or Fisher's tests. The MannWhitney $U$ test was used for comparisons between paired groups if the data were not normally distributed. A P value of $<0.05$ was accepted as statistically significant.

\section{RESULTS}

A total of 5583 patients were examined in the toxicology intensive care unit of Konya Research and Training Hospital between January and August 2016. Among these, 202 were included in the study following the file investigation.

The patient group was composed of 97 (48\%) males and 105 (52\%) females. The median age (IQR) was 32.5 (21) years. Among the participants, 87 (43.1\%) were aged between 18-30, 98 (48.5\%) were aged between 31-60 and 17 (8.4\%) were over 60 years. The patient distribution according to BMI revealed 75 patients (37.1\%) within the 18-24.9 BMI interval, and 127 $(62.9 \%) \geq 25 \mathrm{BMI}$. Glasgow Coma Scale classification revealed 4 patients (2\%) in the 3-9 interval, $16(7.9 \%)$ in the 10-12 interval and $182(90.1 \%)$ in the 13-15 interval. Among the participants, causes of intoxication were organophosphate in 106 (52.5\%), sertraline in $49(24.3 \%)$, quetiapine in $28(13.9 \%)$, propranolol in $9(4.5 \%)$, haloperidol in $7(3.5 \%)$, clomipramine in $2(1 \%)$, local anesthetic agents in $2(1 \%)$, bupropion in $1(0.5 \%)$, lamotrigine in $1(0.5 \%)$ and verapamil in $1(0.5 \%)$. Active complaints were present in 136 of 202 patients. Among these, the complaint was nausea/vomiting in 108 patients, chest pain or discomfort in 2 , and confusion in 24 . The remaining 30 patients had other complaints. 
Among the 202 patients, mechanical ventilation was needed in $22(10.9 \%)$, and all were administered standard fluid infusion. Atropine was needed in 35 (17.3\%), PAM was needed in $36(17.8 \%)$, naloxane or anexate was needed in $3(1.5 \%)$, and other treatments were needed in 5 (2.5\%).

The patients included in the study were classified in two groups according to the BMls in obesity classification of the World Health Organization, as the 18-24.9 interval group and the $\geq 25$ group. Statistical calculations that also comprised organophosphate intoxication demonstrated 36 (17.8\%) males and 39 (19.3\%) females in the BMI 18-24.9 interval group, and 61 (30.2\%) males and 66 (32.7\%) females in the BMI $\geq 25$ group, which revealed no significant difference $(p>0.05)$. A statistically significant difference was observed between the BMI groups regarding age, active complaint, hypertension, coronary artery disease, psychiatric disease atrial fibrillation, need for atropine, need for pralidoxime (PAM), duration of mechanical ventilation, duration of intensive care unit stay, age, clinical termination, $\mathrm{WBC}, \mathrm{Hb}, \mathrm{pCO}_{2}$, troponin, $48^{\text {th }}$ hour urea, and $48^{\text {th }}$ hour AST and ALT $(p<0.05)$.

Organophosphate intoxication was observed in 106 (52.5\%) of 202 patients included in the study. The group with organophosphate intoxication was then excluded and a subgroup analysis was performed according to BMI. In this new analysis excluding organophosphate intoxication, the BMI 18-24.9 group included 18 (18,8\%) males and 30 (31.3\%) females, and the BMI $\geq 25$ group included 18 (18.8\%) males and $30(31.3 \%)$ females. A statistically significant difference was observed between the groups formed according to BMI regarding age, psychiatric disease, duration of intensive care unit stay, clinical termination, $\mathrm{pCO}_{2}$, and $48^{\text {th }}$ hour ALT level $(p<0.05)$. All patients who needed mechanical ventilation were in the BMI $\geq 25$ group. Table 1 demonstrates the comparison of the patient population that were grouped according to the $\mathrm{BMI}$, including other types of lipophilic drug intoxication.

\section{DISCUSSION}

In this study, we investigated the prognostic significance of BMI by comparing obese and non-obese groups in poisoning with lipophilic drugs. In our study, active complaints were more common in the obese group; hypertension coronary artery disease, psychiatric disease, atrial fibrillation were more common; the need for atropine and PAM is higher; longer stayed in intensive care; their clinical outcomes were worse. In addition, all of the patients on mechanical ventilators were in the group with $\mathrm{BMI} \geq 25$.

In drug intoxications, distribution of the drug into different sites of the body depends on the physicochemical characteristics of the drug, such as its molecular size, ionizing degree, lipid solubility, and the ability to be carried through biological membranes. ${ }^{[9,10]}$ In drug intoxications with high lipophilic property, the agents are accumulated in the liver, kidneys, and fat tissue. They are then re-distributed, which may lead to further side effects. Starting at that point, the effects of a drug will depend on the weight of a patient. The patients may have the same weight while having different heights. Thus, the fat amounts will differ, and BMI may be important in the followup of patients in intoxications with high lipophilic drugs.

\begin{tabular}{|c|c|c|c|}
\hline & $\begin{array}{l}\text { BMI 18- } \\
24,9\end{array}$ & $\mathrm{BMI} \geq 25$ & $P$ value \\
\hline Age, year, median (IQR) & $22(6)$ & $35.5(13)$ & $<0.001$ \\
\hline \multicolumn{4}{|l|}{ Gender, n (\%) } \\
\hline Male & $18(18.8)$ & $18(18.8)$ & \multirow{2}{*}{1.00} \\
\hline Female & $30(31.3)$ & $30(31.3)$ & \\
\hline Diabetes mellitus, n (\%) & $0(0)$ & $1(100)$ & 1.00 \\
\hline Hypertension, n (\%) & $0(0)$ & $2(100)$ & 0.49 \\
\hline CAD, n (\%) & $0(0)$ & $2(100)$ & 0.49 \\
\hline Psychiatric illness, n (\%) & $5(22.7)$ & $17(77.3)$ & 0.004 \\
\hline COPD or asthma, $\mathrm{n}(\%)$ & $0(0)$ & $3(100)$ & 0.24 \\
\hline Other disease, n (\%) & $5(55.6)$ & $4(44.4)$ & 1.00 \\
\hline GCS, median (IQR) & $15(0)$ & $15(1)$ & 0.09 \\
\hline Active complaints, $\mathrm{n}(\%)$ & $23(41.8)$ & $32(58.2)$ & 0.06 \\
\hline Nausea, vomiting, n (\%) & $19(43.2)$ & $25(56.8)$ & 0.21 \\
\hline Blur of consciousness, $\mathrm{n}(\%)$ & $3(37.5)$ & $5(62.5)$ & 0.71 \\
\hline Other complaints, n (\%) & $4(50)$ & $4(50)$ & 1.00 \\
\hline Normal ECG, n (\%) & $45(52.9)$ & $40(47.1)$ & 0.19 \\
\hline Ventricular extra systole, n (\%) & $0(0)$ & $1(100)$ & 1.00 \\
\hline Tachycardia or bradycardia, n (\%) & $3(37.5)$ & $5(62.5)$ & 0.71 \\
\hline Atrial Fibrillation, n (\%) & $0(0)$ & $3(100)$ & 0.24 \\
\hline Naloxane or anexate need, n (\%) & $0(0)$ & $3(100)$ & 0.24 \\
\hline $\begin{array}{l}\text { Intubation/mechanical ventilation } \\
\text { requirement, } \mathrm{n}(\%)\end{array}$ & $0(0)$ & $4(100)$ & 0.11 \\
\hline ICU stay day, median (IQR) & $2(0)$ & $3.5(1)$ & \multirow[t]{2}{*}{$<0.001$} \\
\hline $\begin{array}{l}\text { Connecting to a mechanical } \\
\text { ventilator, } \mathrm{n}(\%)\end{array}$ & $0(0)$ & $4(100)$ & \\
\hline $\begin{array}{l}\text { Clinical outcome,n (\%) } \\
\text { Discharge } \\
\text { Transfer } \\
\text { Ex }\end{array}$ & $\begin{array}{c}47(49) \\
1(1) \\
0(0)\end{array}$ & $\begin{array}{c}41(42.7) \\
7(7.3) \\
0(0)\end{array}$ & 0.05 \\
\hline
\end{tabular}

Koo Young Jung et al. ${ }^{[1]}$ demonstrated that the duration of mechanical ventilation, the need for intensive care and the total duration of hospital stay were higher in obese patients $(B M I \geq 25)$ in the high lipophilic drug group, and that in organophosphate intoxication, in particular, the high BMI was significantly related to a bad prognosis. Yusuke Sasabuchi et al. ${ }^{[12]}$ demonstrated that the total duration of stay in the intensive care unit and hospital was longer in this group. In our study, patients accepted as obese according to BMI were found to remain on mechanical ventilation and in the intensive care unit longer, for both organophosphate intoxicationincluded and -excluded groups.

Akalın et al. ${ }^{[13]}$ demonstrated in their study that patients with low GCS among those who had been admitted to the hospital due to organophosphate intoxication, had stayed in the hospital for a longer duration. They also reported that values such as GCS, p.cholinesterase, and creatinine were independent predictive values and that the need for atropin and PAM for patients with diabetes mellitus, hypertension, 
obesity, coronary artery disease, cardiac arrhythmias (atrial fibrillation, etc) and comorbidities were higher. In our study, a history of hypertension, coronary artery disease and a.fibrillation in obese patients in the group that included organophosphate intoxication was higher compared to other groups and the need for atropine and PAM were higher.

Yaegashi et al. ${ }^{[14]}$ reported that obese patients needed interim care units to a higher extent. James et al. ${ }^{[15]}$ used conventional risk adjustment methods including disease severity and comorbidities, and found no correlation between the BMI category and extubation or transfer to interim care unit, or death risk. ${ }^{[15-17]}$ In our study, the obese patient group stayed in intensive care 1.75 times longer. In addition, the rate of transfer to another clinic was 7 times higher in the obese patient group. There was a significant difference was observed between with and without organophosphate intoxication groups regarding BMls and clinical terminations.

In the current literature, there are studies demonstrating that psychiatric diseases are more common among obese patients. ${ }^{[18-20]}$ In our study, a history of the psychiatric disease was observed to be more common among obese patients according to BMI.

There is no clear evidence in the current literature indicating more common active complaints in the obese group with lipophilic drug intoxication. In our study, the presence of active complaints were observed to be more common among obese patients in the group with organophosphate intoxication.

In the current literature, there is no clear evidence showing the relationship between high $\mathrm{BMI}$ and high laboratory values in lipophilic drug intoxication. In our study, Wbc, $\mathrm{Hb}, \mathrm{PCO}_{2}$, troponin, ALT and $48^{\text {th }}$ hour urea, $48^{\text {th }}$ hour AST and $48^{\text {th }}$ hour ALT values were found to be higher in the obese group. In the subgroup analysis in which organophosphate intoxications were excluded, $\mathrm{PCO}_{2}, 48^{\text {th }}$ hour ALT values were found to be higher in the obese group.

\section{CONCLUSION}

Examination of the BMI of a patient may provide useful information for physicians to predict the clinical progression and maybe a guide for the re-evaluation of patients with lipophilic drug intoxication. BMI may be considered as a prognostic factor for the follow-up of patients with lipophilic drug intoxication; however, further studies are needed to clear the subject.

\section{Limitations}

Our study is the first to investigate the effect of BMI on the prognosis in lipophilic drug intoxication comprehensively. However, it was a retrospective study and the data of the patients were obtained in a limited manner. The sample size was limited as well.

In our study, BMI was calculated according to the weight and height of the patients. However, in order to correctly measure obesity, prospective studies that use body fat analyzers are needed.
Since factors such as insufficient sample size for patients admitting with bupropion, lamotrigine, verapamil, clomipramine and local anesthetic agent intoxication, and the fact that organophosphate group drug intoxication formed the majority of the patient population $(52,5 \%)$ may lead to a misevaluation that the data seemed to belong to a single drug group, further studies that include sufficient sample size for each patient group are needed for more accurate outcomes.

\section{ETHICAL DECLARATIONS}

Ethics Committee Approval: Necmettin Erbakan University School of Medicine, Scientific Research Evaluation Committee with a decision no: 2016/16-96.

Informed Consent: Because the study was designed retrospectively, no written informed consent form was obtained from patients.

Referee Evaluation Process: Externally peer-reviewed.

Conflict of Interest Statement: The author(s) declared no potential conflicts of interest with respect to the research, authorship, and/or publication of this article.

Financial Disclosure: The authors declared that this study has received no financial support.

Author Contributions: All of the authors declare that they have all participated in the design, execution, and analysis of the paper, and that they have approved the final version.

\section{REFERENCES}

1. Özköse $Z$ and Ayoĝlu F. Etiological and demographical characteristics of acute adult poisoning in Ankara, Turkey. Human Exp Toxicol 1999;18:6148.

2. Li L, Yang X. The essential element manganese, oxidative stress, and metabolic diseases:links and interactions. Oxid Med Cell Longev 2018;2018.

3. Mert E, Bilgin N, Erdoğan $\mathrm{K}$, et al. Acil servise başvuran akut zehirlenme olgularinin değerlendirilmesi. J Acad Emerg Med 2006;4:14-9.

4. Allard J, Le Guillou D, Begriche K, et al. Drug-induced liver injury in obesity and nonalcoholic fatty liver disease. Adv Pharmacol (San Diego, Calif) 2019;85:75-107.

5. Gómez-Ambrosi J, Silva C, Galofré J, et al. Body mass index classification misses subjects with increased cardiometabolic risk factors related to elevated adiposity. Int J Obes 2012;36:286-94.

6. Kayıpmaz AE, Gülalp B, Benli S. Lipofi lik Ajan Toksisitesinde Yeni Ufuklar Journal of Academic Emergency Medicine/Akademik Acil Tip Olgu Sunumlari Derg 2011;10.

7. Blanco J, Arévalo F, Correa J, et al. Lipophilic Toxins in Galicia (NW Spain) between 2014 and 2017:Incidence on the Main Molluscan Species and Analysis of the Monitoring Efficiency. Toxins 2019;11:612.

8. Cevik SE, Tasyurek T, Guneysel O. Intralipid emulsion treatment as an antidote in lipophilic drug intoxications. Am J Emerg Med 2014;32:1103-8.

9. Katzung B. Drugs used in asthma:Basic and Clinical Pharmacology. Florida:Lange 2007:690.

10. Gunnell D, Eddleston M, Phillips MR, et al. The global distribution of fatal pesticide self-poisoning:systematic review. BMC Public Health 2007;7:357.

11. Lee $\mathrm{DH}$, Jung $\mathrm{KY}, \mathrm{Choi} \mathrm{YH}$, et al. Body mass index as a prognostic factor in organophosphate-poisoned patients. Am J Emerg Med 2014;32:693-6. 
12. Sasabuchi $Y$, Yasunaga $H$, Matsui $H$, et al. The dose-response relationship between body mass index and mortality in subjects admitted to the ICU with and without mechanical ventilation. Respir Care 2015;60:983-91.

13. Acikalin A, Dişel NR, Matyar $S$, et al. Prognostic factors determining morbidity and mortality in organophosphate poisoning. Pakistan J Med Sci 2017;33:534.

14. Yaegashi $M$, Jean $R$, Zuriqat $M$, et al. Outcome of morbid obesity in the intensive care unit. J Intens Care Med 2005;20:147-54.

15. O'Brien Jr JM, Philips GS, Ali NA, et al. The association between body mass index, processes of care, and outcomes from mechanical ventilation:a prospective cohort study. Crit Care Med 2012;40:1456-63.

16. O'Brien Jr JM, Phillips GS, Ali NA, et al. Body mass index is independently associated with hospital mortality in mechanically ventilated adults with acute lung injury. Crit Care Med 2006;34:738.

17. O'Brien JM, Welsh $\mathrm{CH}$, Fish RH, et al. Excess body weight is not independently associated with outcome in mechanically ventilated patients with acute lung injury. Ann Intern Med 2004;140:338-45.

18. Preljevic VT, Østhus TBH, Sandvik L, et al. Psychiatric disorders, body mass index and C-reactive protein in dialysis patients. Gen Hosp Psychiatry 2011;33:454-61.

19. Hartwig FP, Bowden J, De Mola CL, et al. Body mass index and psychiatric disorders:a Mendelian randomization study. Sci Rep 2016;6:32730.

20. Solmi M, Collantoni E, Meneguzzo P, et al. Network analysis of specific psychopathology and psychiatric symptoms in patients with eating disorders. Int J Eat Disord 2018; 51:680-92. 